\title{
REVISITING INTERNATIONAL ADMINISTRATIVE LAW AS A LEGAL DISCIPLINE
}

Doc. JUDr. Jakub Handrlica*

\author{
UDK 342.92 \\ https://doi.org/10.30925/zpfsr.39.3.5 \\ Ur.: 15. srpnja 2018. \\ Pr.: 26. listopada 2018. \\ Prethodno priopćenje
}

\section{Summary}

The term "international administrative law" is understood in two separate ways. On one hand, the authors (diritto internazionale amministrativo) used this term regarding the administrative competencies of various international administrative unions, as provided by applicable international conventions. On the other hand, other authors (e.g. Karl Neumeyer, Paul Négulescu, Giuseppe Biscottini) used the term to exclusively refer to the norms of national law (diritto amministrativo internazionale, droit administratif international, internationales Verwaltungsrecht), which address certain foreign elements. This article follows the second understanding of the term "international administrative law." For a long time, these norms had been quite rare in administrative law and, consequently, the legal scholarship did not pay much attention to the discipline of international administrative law. However, most recently, the sources of EU law increasingly require reflection of certain foreign elements in the norms of administrative law. In this respect, this article argues that international administrative law represents a legal discipline that is fully capable of addressing those problems arising by the application of these norms in administrative law.

Keywords: $\quad$ international administrative law; mutual recognition of foreign administrative acts; acta iure imperii; qualification problem; jurisdictional immunity of the State.

\section{INTRODUCTION ${ }^{1}$}

Traditionally, the science of administrative law hadn't dealt with those issues

* Doc. JUDr. Jakub Handrlica, Ph.D., Associate Professor, Faculty of Law, Charles University in Prague, Czech Republic; jakub.handrlica@prf.cuni.cz.

1 This article is based on my habilitation thesis entitled "Transterritorial Administrative Acts: A Study in International Administrative Law," which was defended before the Scientific Committee on $12^{\text {th }}$ October, 2017, prior to being promoted to Associate Professor in Administrative Law at the Law Faculty, Charles University in Prague. 
involving foreign elements. Under this traditional approach, administrative law dealt exclusively with domestic administrative regulations (Befehlsgewalt) and their application by domestic administrative authorities in the territory of the State (Zwangsgewalt). ${ }^{2}$ Consequently, any issues involving foreign elements ${ }^{3}$ were basically left as subjects of interest in the scholarship of international law. ${ }^{4}$ Thus, under the traditional approach to the administrative law, any "international administrative law" had to be considered as a kind of a contradictio in adjecto. In effect, most of the recent textbooks on administrative law do not deal with cases involving foreign elements or only marginally deal with them. ${ }^{5}$

It is a matter of fact that the term "international administrative law" has been understood in two rather different ways. In this respect, Italian scholar Donato Donatti already argued ${ }^{6}$ in 1906 for the existence of two separate legal disciplines: on one hand, there was diritto internazionale amministrativo as a branch of international law and on the other, he argued for existence of diritto amministrativo internazionale as a branch of administrative law.

Consequently, many scholars ${ }^{7}$ used the term international administrative law when addressing those norms of international law that deal with the competencies of international administrative unions. ${ }^{8}$ This branch of legal scholarship established the foundations of the law of international organizations.

2 Vogel, Klaus, Administrative Law. International Aspects, In: Encyclopedia of Public International Law, Vol. 9 - International Relations and Legal Co-operation in General, Amsterdam, North Holland, 1986, pp. 4-5.

3 E.g. the cases of application of administrative law towards persons enjoying status of extraterritoriality, application of domestic administrative law by the diplomatic officials towards the citizens of the State in the territory of a third country, recognition of foreign administrative acts in the territory of the State, issuance of passports, foreign economic activities etc.

4 Hoffman, G., Internationales Verwaltungsrecht, In: Münch, I. (ed.), Besonderes Verwaltungsrecht, Berlin, De Gruyter, 1985, pp. 851-862.

5 Erichsen, H., Ehlers, D. (eds.), Allgemeines Verwaltungsrech, Berlin, De Gruyter, 2010, pp. 188-192.

6 Vogel, K., op. cit., pp. 4-5.

7 Kazansky, P., Les premiers éléments de l'organisation universelle, RDILC, vol. XXIX, 1/1897, pp. 238-247, Kazansky, P., Théorie de l'administration internationale, RGDIP, vol. IX, 1/1902, pp. 353-376, Reinsch, P., Public International Unions: Their Work and Organization. A Study in International Administrative Law, Boston, Ginn \& Company 1911, Kaufmann, W., Les unions internationales, RCADI, vol. 2, 2/1924, pp. 177-290, Rapisardi-Mirabelli, A., Théorie générale des unions internationals, RCADI, vol. 3, 2/1925, 341-393, Rapisardi-Mirabelli, A., Die Internationalen Unionen als Form der völkerrechtlichen Organisation, ZÖR, vol. 7, 1/1927, pp. 11-21, Rapisardi-Mirabelli, A., Diritto internazionale amministrativo, Padova, Cedam, 1939, Carlston, Kenneth, International Administrative Law: A Venture in Legal Theory, Emory University Law School, 1959, etc. Recently, the term "international administrative law" is also used to refer to international networks of administrative agencies. See Kinney, E., The emerging field of international administrative law: its content and potential, ALR, vol. 54, 1/2002, pp. 415-433.

8 International Telegraph Union, International Meteorological Organisation, General Postal Union, International Bureau of Weights and Measures, International Patent Bureau, International Union for Seismology, Union of the Exploration of the Sea, International Commission for Air Navigation, International Union for Geodesy and Geophysics, International Railway Union etc. 
Other scholars ${ }^{9}$ argued that international administrative law ${ }^{10}$ represents a special branch of domestic administrative law. Under this understanding, scholars paid attention to those provisions of administrative law that addressed cases with foreign elements. In this respect, it was argued that, in dualistic systems, only provisions of domestic law are capable to address those cases where a foreign element is involved by the application of administrative law. Consequently, this school of international administrative law, represented in particular by Prospero Fedozzi, Paul Négulescu, Karl Neumeyer, Guiseppe Biscottini and Prosper Weil, paid particular attention to those provisions of administrative law that referred to a "foreign element". ${ }^{11}$

It is a matter of fact that the provisions addressing the above mentioned problems were rare in the past. In this respect, the mere existence of international administrative law was once questioned. ${ }^{12}$ However, most currently, several authors ${ }^{13}$ pointed out that the provisions of EU law increasingly provide fertile ground for this specific branch of administrative law.

Consequently, this article aims to deal with the several situations in which a

9 Fedozzi, P., Il Diritto Amministrativo Internazionale (Nozioni Sistematiche), Perugia, Unione Tipografica Cooperativa, 1901, Borsi, U., Carattere e oggetto del diritto amministrativo internazionale, RDI, vol. 2, 2/1912, pp. 352-378, Gascón y Marín, J., Les transformations du droit administratif international, RCADI, vol. 33, 1/1930, pp. 1-76, Négulescu, P., Principes du droit international administratif, RCADI, vol. 4, 4/1935, pp. 579-692, Neumeyer, K., Internationales Verwaltungsrecht, Allgemeiner Teil, Zürich, Verlag für Recht und Gesellschaft, 1936, Schlochauer, H., Internationales Verwaltungsrech, In: Giese, F. (ed.) Die Verwaltung, Köln, 1956, pp. 56-59, Biscottini, G., Diritto ammunistrativo internazionale, Padova, Antonio Milani, 1966, Weil, P., Le droit administratif international: bilan et tendences, Paris, Institut des hautes études internationales, 1962, etc.

10 Diritto amministrativo internazionale, droit administratif international, internationales Verwaltungsrecht.

11 Concerning a theoretical determination of "international administrative law" see Neumeyer, K., op.cit., pp. 450-452 and 476-480. For alternative views, see Issay, E., Internationales Verwaltungsrecht, In: Stier-Slomo, F., Elster, A. (eds.) Handwörterbuch der Rechtswissenschaft, vol. 3, Berlin, De Gruyter, 1928, pp. 344-354, Hoffmann, G., Internationales Verwaltungsrecht, In: Münch, I. (ed.) Besonderes Verwaltungsrecht, Berlin, De Gruyter, 1985, pp. 851-862 and Vogel, K., Der räumliche Anwenndungsbereich der Verwaltungsnormen, Frankfurt am Main, Alfred Metzner Verlag, 1965, pp. 310-316.

12 Matscher, F., Gibt es ein internationales Verwaltungsrecht? In: Sandrock, O. (ed.), Festschrift für Günther Beitzke, Berlin, De Gruyter, 1979, pp. 641-649.

13 Battini, Stefano, Il diritto amministrativo internazionale, Riv. it. dir. pubbl. com., 10/2010, pp. 1405-1427, Biaggini, G., Die Entwicklung eines Internationalen Verwaltungsrechts als Aufgabe der Rechtswissenschaft, In: Nolte, G., Poscher, R., Hillgruber, C. (eds.), Die Leistungsfähigkeit der Wissenschaft des Öffentlichen Rechts, Berlin, De Gruyter, 2008, pp. 413-445, Breining-Kaufmann, Christine, Internationales Verwaltungsrecht, Zeitschrift für Schweizerisches Recht, vol. 125, 1/2006, pp. 7-46, Ohler, C., Internationales Verwaltungsrecht - ein Kollisionsrecht eigener Art? In: Leible, S., Ruffert, M. (eds.), Völkerrecht und IPR, Jena, Jaener Wissenschaftlicher Verlag, 2006, pp. 131-148, Ruffert, M., Perspektiven des Internationalen Verwaltungsrechts, In: Möllers, C., Vosskuhle, A., Walter, C. (eds.), Internationales Verwaltungsrecht, Tübingen, Mohr Siebeck, 2007, pp. 395-420, Menzel, Jörg, Internationales Öffentliches Recht, Verfassungs- und Verwaltungsgrenzrecht in Teiten der offenen Staatlichkeit, Tübingen, Mohr Siebeck, 2011 etc. 
foreign element is addressed by administrative authorities in individual cases. ${ }^{14}$ This will be demonstrated by regarding three different topics that arise by mutual recognition of foreign administrative acts. Accordingly, this article aims to argue that international administrative law represents a legal discipline that is capable of addressing those problems arising from application of those provisions of the EU law that refer to a foreign element in the relations of administrative law.

\section{PROBLEMS OF INTERNATIONAL ADMINISTRATIVE LAW REVISITED}

\subsection{Introduction}

Traditionally, the term "recognition of foreign administrative acts" (active mutual recognition) had been understood ${ }^{15}$ as recognition ex actu. That means that a foreign administrative act ${ }^{16,17}$ is to be recognized by another State, based on a decision of recognition (decision de reconnaissance). Thus, based on the principle of sovereign equality of the States, each State basically had the freedom to recognize, or not, the administrative acts of other States. ${ }^{18}$ Further, the decision of recognition remained to be an act of the recognizing State and, consequently, such recognition could be

14 Consequently, the issue of trans-territorial (extraterritorial) effects of laws and decrees in the field of administrative law will not be a subject of this article.

15 Biscottini, G., L'efficacité des actes administratifs étrangers, RCADI, vol. 103, 5/1961, 638696, König, K., Die Anerkennung der ausländischen Verwaltungsakten, Köln, C. Heymann, 1965, Pamboukis, C., L'acte public étranger en droit international privé, Paris, L.G.D.J., 1993, idem, La renaissance-métamorphose de la méthode de reconnaissance, Rev.crit. DIP, 2008, pp. 513-528, Mayer, Pierre, Les méthodes de la reconnaissance en droit international privé, In: Mélanges en 1'honneur de Paul Lagarde, Le droit international privé : esprit et méthodes, Paris, Ed. Dalloz, 2005, pp. 547-552, Schlochauer, H., Die extraterritoriale Wirkung von Hoheitsakten nach dem öffentlichen Recht der Bundesrepublik Deutschland und nach internationalem Recht, Frankfurt am Main, Vittorio Klosterman, 1962, Weiss, K., Die Annerkennung ausländischer Verwaltungsakte, Flentje, Verlag Seesen, 1932 etc.

16 The terminology deserves certain clarification. It is a fact that there isn't any common understanding concerning the meaning of the term "administrative act". The term is understood differently in various jurisdictions (Verwaltungsakt, acte administratif unilateral, atto amministrativo). For the purpose of this article, the term aims to address all types of unilateral administrative measures issued by the concerned State. Consequently, by using the term "administrative act", this article will also understand administrative measures such as university diplomas, driver's licences, certificates of airworthiness etc. This approach was already chosen by Matthias Ruffert in his habilitation lecture (subsequently published as "Der Transnationale Verwatlungsakt", Verw, vol. 34, 3/2001, pp. 475-476) and is currently generally accepted among legal scholars.

17 In the scholarship of international private law, the authors frequently used to distinguish between "public acts" and "quasi-public acts" (e.g. diplomas, certificates, licences etc.). See e.g. Pamboukis, Ch., L'acte quasi public en droit international privé, Rev. crit. DIP, 1993, pp. 565-585.

18 Bollée, S., Les conditions de la reconnaissance, notamment à la lumière des conventions internationales, In: Lagarde, P. (ed.) La reconnaissance des situations en droit international privé, Paris, Éd. A. Pedone, 2013, pp. 112-122. 
withdrawn by annulment or cancelation of such a decision.

On the contrary, ${ }^{19}$ cases of recognition of foreign administrative acts provided by directly applicable provisions of administrative law (recognition ex lege) were once traditionally rare. In the fourth volume of his monumental work on "International Administrative Law", Karl Neumeye ${ }^{20}$ mentioned cases of such mutual recognition, based on existing international treaties. ${ }^{21}$ In this regard, Neumeyer argued ${ }^{22}$ that, in dualist legal systems, the legal effects of foreign administrative acts that are provided by those directly applicable provisions of domestic law, which provide for the reception of corresponding international conventions.

It is a fact that international law provides certain examples of recognition ex lege, such as driving permits, ${ }^{23}$ certificates of airworthiness, certificates of competency, pilot licenses ${ }^{24}$ and the laissez-passer for a corpse $e^{25}{ }^{26} \mathrm{~A}$ title for the legal effects of a foreign administrative act in the territory of the concerned State is provided by applicable law providing for reception of the corresponding international treaty. ${ }^{27}$

However, it has been EU law that used this model of recognition in various areas of administrative law. Currently, this is the case of authorizations for pursuing undertakings of collective investment in transferable securities ${ }^{28}$ and authorizations for pursuing investment services, ${ }^{29}$ insurance services, ${ }^{30}$ management of alternative

19 For a detailed explanation of differences between both models of recognition, see Schwarz, M., Europa in der Horizontalen: Zur Abgrenzung des Prinzips gegenseitiger Anerkennung von Rechtsinstitut des transnationalen Verwaltungsaktes, In: Debus, A., Kruse, F., Peters, A. (eds), Verwaltungsrechtsraum Europa, Baden Baden, Nomos Verlag, 2011, pp. 53-69.

20 Neumeyer, K., op.cit., pp. 295-296.

21 The Convention with Respect to the International Circulation of Motor Vehicles of 1909, the Berlin Convention on the Transport of Corpses of 1937.

22 Neumeyer, K., op. cit., pp. 477-478.

23 The Geneva Convention on Road Traffic of 1949, the Vienna Convention on Road Traffic of 1968.

24 The Chicago Convention on International Civil Aviation of 1944.

25 The Agreement of the Transport of Corpses of 1973.

26 The Agreement concerning the Adoption of Harmonized Technical United Nations Regulations for Wheeled Vehicles, Equipment and Parts which can be Fitted and/or be Used on Wheeled Vehicles of 1958 and the intergovernmental Convention for the Reciprocal Recognition of Proof Marks on Small Arms and Ammunition of 1969 provide additional examples.

27 The model has historic parallels in cases of mutual recognition of certain documents (e.g. university diplomas, apprenticeship certificates etc.) in medieval Europe, which was based on common law. It is also worth mentioning that parallels also exist to some extent in ecclesiastical law (e.g. mutual recognition of baptismal certificates between the Catholic Church and the Russian Orthodox Church).

28 Directive 2009/65/EC of the European Parliament and of the Council of 13 July 2009 on the coordination of laws, regulations and administrative provisions relating to undertakings for collective investment in transferable securities (UCITS), OJ L 302 of 17.11.2009.

29 Directive 2014/65/EU of the European Parliament and of the Council of 15 May 2014 on markets in financial instruments and amending Directive 2002/92/EC and Directive 2011/61/ EU, OJ L 173 of 12.6.2014.

30 Directive 2009/138/EC of the European Parliament and of the Council of 25 November 2009 on the taking-up and pursuit of the business of Insurance and Reinsurance (Solvency II), OJ L 335 of 17.12.2009. 
investment funds ${ }^{31}$ as well as by the activity of credit institutions ${ }^{32}$ etc. It is a distinguished feature of this model of administrative acts that their legal effects outside the territory of the State are produced here directly by the applicable law that implemented the corresponding directive..$^{33}$ In all these cases, the legal effects of foreign administrative acts arise in the territory of another State, based on corresponding piece of domestic legislation of the State that implemented the applicable EU directive. In this regard, it is also argued that legal effects will also arise within the territory of any State that fails to implement such requirements correctly or refuses to implement them at all. ${ }^{34}$

Consequently, these "trans-territorial administrative acts" ${ }^{35}$ require no decision de reconnaissance in order to produce legal effects in the territory of other States (as necessary in the model of active mutual recognition), but merely require a formal notification procedure (passive mutual recognition) between the competent administrative authority of the home State and the competent authority of the host

31 Directive 2011/61/EU of the European Parliament and of the Council of 8 June 2011 on Alternative Investment Fund Managers and amending Directives 2003/41/EC and 2009/65/EC and Regulations (EC) No 1060/2009 and (EU) No 1095/2010, OJ L 174 of 1.7.2011.

32 Directive 2013/36/EU of the European Parliament and of the Council of 26 June 2013 on access to the activity of credit institutions and the prudential supervision of credit institutions and investment firms, amending Directive 2002/87/EC and repealing Directives 2006/48/EC and 2006/49/EC, OJ L 176 of 27.6.2013.

33 Bleckmann, A., Zur Anerkennung ausländischer Verwaltungsakte im Europäischen Gemeinschaftsrecht, JZ, vol. 40, 10/1985, pp. 1077 - 1086, Bocanegra Sierra, R., Garcia Luengo, J., Los actos administrativos transnacionales, Revista de Administración Pública, num. 177, 2008, septiembre/diciembre, pp. 9-29, De Lucia, L. Administrative Pluralism, Horizontal Cooperation and Transnational Administrative Acts, REALaw, vol. 5, 2/2012, pp. 17-47, Gerontas, A., Deterritorialization in Administrative Law: Exploring Transnational Administrative Decisions, Columbia Journal of European Law, vol. 19, 3/2013, pp. 423-468, Handrlica, J., International Administrative Law and Administrative Acts: Transterritorial Decision Making Revisited, Czech Yearbook of Public \& Private International Law, vol. 7, 2016, pp. 99-100, Kment, M., Grenzüberschreitendes Verwaltungshandeln, Tübingen, Mohr Siebeck, 2010, pp. 511-512, Neßler, V., Der transnationale Verwaltungsakt: zur Dogmatik eines neuen Rechtsinstituts, NVwZ, vol. 14, 10/1995, pp. 863-873, Pernas García, J., The EU's Role in the Progress Towards the Recognition and Execution of Foreign Administrative Acts, In: Rodríguez-Arana Munoz, J. (ed.), Recognition of Foreign Administrative Acts, New York, Springer, 2016, pp. 15-33; Raschauer, B., Transnationale Verwaltungsakten, In: Hammer, S., Stelzer, M., Weichselbaum, B. (eds.), Demokratie und sozialer Rechtsstaat in Europa; Festschrift für Theo Öhlinger, Wien, WUV Universitätsverlag, 2004, pp. 661-686, Ruffert, M., Recognition of Foreign Legislative and Administrative Act, In: Wolfrum, R. (ed.), Max Planck Encyclopedia of Public International Law, Oxford, OUP, 2008, pp. 567-578.

34 Gerontas, A., op. cit., p. 453.

35 In this context, the term "trans-national" or "extra-territorial" is also used by some scholars; see Bocanegra Sierra, R., Garcia Luengo, J., op. cit., De Lucia, L., op. cit., Pernas García, J., op. cit. etc. However, Hertwig Hofmann presented some persuasive arguments in favour for using the term "trans-territorial" in this context. See Hofmann, H., Dealing with Trans-Territorial Executive Rule Making, Mo. L. Rev., vol. 78, 2/2013, pp. 423-442 and idem, Transnational and Trans-Territorial Rule-Making - A Basic Framework, Law Working Papers, University of Luxembourg, 1/2014, pp. 1-40. 
State.$^{36}$ However, it is a fact that, even after establishing legal effects in the territory of another State, the concerned "trans-territorial administrative act" remains an act issued pursuant to the legal framework of the home State.

The fact that the model of passive mutual recognition provides for direct legal effects of foreign administrative acts in the territory of other States implies several crucial questions. These have already been, to a certain degree, addressed by the scholarship of the international administrative law. These questions will be covered in the following paragraphs.

\subsection{Nullity of foreign administrative acts}

When analyzing the model of passive mutual recognition, the concept of nullity of an administrative act (Nichtigkeit des Verwaltungsaktes, nullita' del provvedimeto, nullité des actes administratifs) raises several painful questions. Therefore, the problem of nullity will be discussed as a priority. In several jurisdictions, nullity implies that the administrative act concerned does not provide any legal recourse. ${ }^{37}$ Nullity implies the fact, the concerned administrative act does not exist at all, in contrast to those administrative acts that have been issued in contradiction to the law and may became subject of administrative review (see below sub 2.3.).

Traditionally, the scholars of international administrative law argued that a nullity represents a grave obstacle for active mutual recognition. ${ }^{38}$ "Nullity does not produce any legal effects in the home State and consequently, such effects cannot be enlarged by a decision de reconnaissance abroad." ${ }^{39}$ Quod nullum est, nullum producit effectum. This traditional approach has also been applied by several recent scholars ${ }^{40}$ vis-á-vis the model of passive mutual recognition. Thus, they argued that nullity constitutes an obstacle for required notification procedures and the establishment of any legal effects in the territory of other States.

36 Examples include collective investment in transferable securities (UCITS), whose Directive 2009/65/EC provides in its Art. 17 that a management company, wishing to establish a branch within the territory of another Member State, shall notify the competent authorities of its home Member State. In this respect, the competent authorities require each such management company to provide certain information and documentation. Unless the competent authorities have reason to doubt the adequacy of the administrative structure or the financial situation of the management company, they shall within two months of receiving all information required, communicate that information to the competent authorities of the host Member State and inform the management company accordingly. The branch of the management company may then be established and begin business after receiving communication from the competent authorities of the host Member State or on the expiry of the two month period after these authorities received information from the competent authorities of the home Member State.

37 In several jurisdictions, nullity is considered $a b$ initio, when some grave defects are present (e.g. absence of competence, absence of form, absolute impossibility to fulfil the requirements provided etc.). In other jurisdictions, nullity of a respective act is established only from the date of its declaration by the competent authority.

38 Weiss, K., op. cit., pp. 60-61.

39 König, K., op. cit., pp. 56.

40 Bocanegra Sierra, R., Garcia Luengo, J., op. cit., pp. 24-25, De Lucia, L., op. cit., pp. 34-35, Gerontas, A., op. cit., pp. 456-457 etc. 
Two separate opinions have been expressed in this concern by leading German scholars. Matthias Ruffert argued ${ }^{41}$ that nullity constitutes no obstacles for enlarging legal effects in the model of passive mutual recognition. Ruffert's argument was, in principle, based upon the argument that administrative authorities have no competence to review the legal nature of foreign administrative acts. Gernot Sydow attempted ${ }^{42}$ to accommodate both these opinions by arguing that the provisions of administrative law regarding nullity are not applicable vis-á-vis "trans-territorial administrative acts."

Both these opinions were subject to severe criticism..$^{43}$ Ruffert's view will obviously lead to absurd consequences, when an act being considered as non-existing in the home State establishes legal consequences in the host State. However, Sydow's position is also unsustainable, as it would lead to a situation where the competent authorities of the home State may review the legality of the issued act, yet not be able to declare nullity of a non-existing act.

Consequently, with regard to the model of passive mutual recognition, the issue of nullity must be addressed in line with the principle of loyal cooperation among the administrative authorities of the concerned Member States. ${ }^{44}$ The potential nullity of a foreign administrative act must therefore be notified by the administrative authority of the host State to the competent authority of the home State. It is in the exclusive competence of the competent authority of the home State to declare the nullity of the concerned act and, if so, the applicable law provides for the individual case.

\subsection{Review of foreign administrative acts}

Further questions arise, as to under which situations (and if at all) are the administrative authorities of the host State competent to review the legality of foreign administrative acts. This is rather complex and it will be discussed as a second issue. Traditionally, there have been two different doctrines addressing it:

On one hand, there was a doctrine based on the principle of the jurisdictional immunity of the State. Consequently, Prospero Fedozzi ${ }^{45}$ and Karl Neumeyer ${ }^{46}$ argued that any review of foreign administrative acts by the administrative authorities of the host State would be in strict contradiction with the concept of the jurisdictional immunity of the State. Thus, under this doctrine, administrative acts are considered as acta iure imperii and cannot be reviewed by the administrative authorities of any other State. This opinion, which strictly follows the doctrine of sovereign equality of the States, was later confirmed by several other scholars ${ }^{47}$ when dealing with issues

41 Ruffert, M., Der Transnationale Verwatlungsakt..., pp. 475-476.

42 Sydow, G., Verwaltungskooperation in der Europäischen Union, Tübingen, Mohr Siebeck, 2004, p. 149.

43 De Lucia, L., op. cit., pp. 34-35, Gerontas, A., op. cit., pp. 456-457 etc.

44 De Lucia, L., op. cit., pp. 35.

45 Fedozzi, P., De l'efficacité extraterritotiale des lois et des actes de droit public, RCADI, vol. 32, 1/1929, pp. 200-201.

46 Neumeyer, K., op. cit., pp. 349.

47 Beitzke, G., Extraterritoriale Wirkung von Hoheitsakten, In: Strupp, K., Schlochauer, H. (eds.) Wörterbuch des Völkerrechts, De Gruyter, Berlin, 1960, pp. 505-506, Dahm, G., Die 
of international administrative law. In principle, they claim that the legality of an administrative act can only be reviewed with respect to the law of the home State. ${ }^{48}$ Subsequently, only the administrative authorities of the home State are competent to provide for a review of legality. In fact, this doctrine is currently almost universally accepted by the legal scholarship. ${ }^{49}$ This position was also recently supported by the ECJ. ${ }^{50}$

Yet on the other hand, there is another doctrine, mainly followed by the French scholarship that basically argues in favor of the possibility to review the legality of foreign administrative acts with the respect to the territory of the host State. Thus, this doctrine argues, such a review would not contradict the principle of sovereign equality of the States, as it does not impact the legal consequences of this act in the home State. Consequently, this doctrine argues that the possibility to review a foreign administrative act with respect to its own territory must be considered as part of the sovereignty of the concerned State. It was Nicola Bassi, who recently argued ${ }^{51}$ in favor of this doctrine in his outstanding monograph.

Having briefly analyzed both existing doctrines, it is appropriate to mention that some provisions of EU law explicitly provide for a competence of administrative authority to review acts issued by a foreign State. Such is the case of the Visa Code, ${ }^{52}$ which provides for a competence to annul or revoke an issued visa. In this regard,

Achtung fremder Hoheitsakte, In: Dahm, G., Delbrück, J., Wolfrum, R. (eds.), Völkerrecht, Die Grundlagen, Die Völkerrechtssubjekte, Berlin, De Gruyter, 1989, pp. 490-492, Geck, W., Anerkennung fremder Hoheitsakte, In: Strupp, K., Schlochauer, H. (eds.) Wörterbuch des Völkerrechts, De Gruyter, Berlin, 1960, s. 55-57, König, K., op. cit., pp. 101-102, Magerstein, W. Hoheitsakte fremder Staaten und ordre public, JBl, vol. 76, 3/1954, pp. 424 436, Morgenstern, F., Recognition and Enforcement of Foreign Legislative, Administrative and Judicial Acts which are contrary to International Law, ILQ, vol. 4, 3/1951, pp. 326-344, Siegrist, D., Hoheitsakte auf fremdem Staatsgebiet, Zürich, Schulthess Verlag, 1987, pp. 22-24, Wenander, H. Recognition of Foreign Administrative Decisions, ZaöRV, vol. 71, 1/2011, pp. $755-785$.

48 Handrlica, J., Foreign Law as Applied by Administrative Authorities: Grenznormen Revisited, Collected Papers of Zagreb Law Faculty, vol. 68, 2/2018, pp. 198-199.

49 Burbaum, S., Rechtsschutz gegen transnationales Verwaltungshandeln, Baden Baden, Nomos Verlag, 2003, pp. 84-99, De Lucia, L., op. cit., pp. 32-35, Gerontas, A., op. cit., pp. 454-455, Neßler, V., op. cit., p. 864, Ritleng, D., Le retrait des actes administratifs contraires au droit communautiare, In: Schwarze, J. (ed.), L'état actuel et les perspectives du droit administratif européen, Brussels, Bryulant, 2010, pp.. 251-271, Sydow, G., op. cit., pp. 30-31 etc.

50 "Inasmuch as Directive (...) confers on the issuing Member State exclusive competence to check that driving licences are issued in compliance with the requirements imposed by that directive, it is for that Member State alone to take appropriate measures (highlighted by the author) in respect of which it is subsequently established that the holders did not satisfy those conditions." Decision of $26^{\text {th }}$ June 2008, Wiedemann C-329/06 and Funk C-343/06, EU:C:2008:366, sub 56.

51 Bassi, N., Mutuo riconoscimento e tutela giurisdizionale, Milano, Giuffré Editore, 2008, pp. 87-91. Here, Bassi argues particularly in favour of the possibility for judicial review of those "trans-territorial" administrative acts that affect rights of subjects in the host State. To some extent, the opinion was also shared by Danwitz, T., Europäisches Verwaltungsrecht, Heidelberg, Springer Verlag, 2008, p. 646, ft. 234.

52 Regulation (EC) No 810/2009 of the European Parliament and of the Council of 13 July 2009 establishing a Community Code on Visas (Visa Code), OJ L 243 of 15.9.2009. 
the Visa Code provides (Art. 34, Paragraph 1) that a visa shall be annulled ${ }^{53}$ where it becomes evident that the conditions for issuing it were not met at the time it was issued, if there are serious grounds for believing that the visa was fraudulently obtained. A visa shall, in principle, be annulled by the competent authorities of the Member State that issued it. A visa may also be annulled by the competent authorities of another Member State, in which case the authorities of the Member State that issued the visa shall be informed of such annulment.

Further, the Visa Code also provides (Art. 34, Paragraph 2) that a visa shall be revoked where it becomes evident that the conditions for issuing it are no longer met. A visa shall, in principle, be revoked by the competent authorities of the Member State which issued it, although it may be revoked by the competent authorities of another Member State, in which case the authorities of the Member State that issued the visa shall be informed of such revocation. ${ }^{54}$ Finally, the Visa Code provides (Art. 34, Paragraph 3) that a visa may be revoked at the request of the visa holder. The competent authorities of the Member States that issued the visa shall be informed of such revocation.

These cases represent rare examples of provisions that provide for competence of the host State to annul or revoke a foreign administrative act. However, such provisions must be considered exceptions from the basic principle that confers such competence exclusively to the hands of the home State. In this regard, the applicable directives regularly provide an obligation to inform the concerned authorities of the host States concerning the fact that an administrative act has been annulled or revoked. ${ }^{55}$

Having said this, we must also mention that the existing sources of EU law also provide for several other measures ${ }^{56}$ whose aim is to protect the public interests by the competent authorities of the host State.

Several sources of EU law provide for a competence of an administrative authority to refuse trans-territorial effects of an act to protect public interests of

53 In this respect, the Visa Code provides (Art. 34, paragraph 5) that, if a visa is annulled or revoked, a stamp stating 'ANNULLED' or 'REVOKED' shall be affixed to it and the optically variable feature of the visa sticker, the security feature 'latent image effect' as well as the term 'visa' shall be invalidated by being crossed out.

54 In this respect, the Visa Code provides (Art. 34, paragraph 7), that a visa holder whose visa has been annulled or revoked shall have the right to appeal, unless the visa was revoked at his request in accordance with paragraph 3. Appeals shall be conducted against the Member State that has taken the decision on the annulment or revocation and in accordance with the national law of that Member State. Member States shall provide applicants with information regarding the procedures to be followed in the event of an appeal, as specified in Annex VI.

55 E.g. the Directive 2009/138/EC provides (Article 144, Paragraph 2) that, in the event of the withdrawal or lapse of authorisation, the supervisory authority of the home Member State shall notify the supervisory authorities of the other Member States accordingly and those authorities shall take appropriate measures to prevent the insurance or reinsurance undertaking from commencing new operations within their territories. The supervisory authority of the home Member State shall, together with those authorities, take all measures necessary to safeguard the interests of insured persons and, in particular, shall restrict the free disposal of the assets of the insurance undertaking in accordance with Article 140.

56 Ruffert, M., Recognition..., pp. 576-577. 
their or other States. Such competence can be conferred either to the administrative authorities of the home State, ${ }^{57}$ or to the authorities of the host State..$^{58}$ The legal effects of such refusal (some authors ${ }^{59}$ also refer to blocking of legal effects) are limited to the territory of the concerned State and their primary goal is to prevent the phenomenon of forum shopping. With respect to the model of passive mutual recognition, some authors argued ${ }^{60}$ that these competencies, in fact, jeopardize the effectiveness of the established model. Consequently, the EJC also argued that the competence must be interpreted in a restrictive way. ${ }^{61}$

While the competence to refuse the trans-territorial effects aims primary to

57 E.g. the Directive 2009/65/EC provides (Article 17, Paragraph 3), that where the competent authorities of the management company's home Member State refuse to communicate the information referred to in paragraph 2 to the competent authorities of the management company's host Member State, they shall give reasons for such refusal to the management company concerned within two months of receiving all the information. The refusal or any failure to reply shall be subject to the right to apply to the courts in the management company's home Member State.

58 E.g. the Directive 2009/126/EC provides (Article 11, Paragraph 4), that a Member State shall refuse to recognise the validity of any driving license issued by another Member State to a person whose driving license is restricted, suspended or withdrawn in the former State's territory. A Member State may also refuse to issue a driving license to an applicant whose license is cancelled in another Member State.

59 Burbaum, S., op. cit., pp. 56-59.

60 De Lucia, L., op. cit., p. 27.

61 "Second, the first subparagraph of Article 8(4), which authorises a Member State to refuse to recognise the validity of a driving license obtained in another Member State by a person who is, in the first Member State's territory, the subject of a measure restricting, suspending, withdrawing or cancelling a license, constitutes a derogation from the general principle of mutual recognition of driving licenses and is, therefore, to be interpreted strictly (highlighted by the author). (...) Nor may that provision be relied on by a Member State to refuse indefinitely to recognize, in relation to a person who has been the object in its territory of a measure withdrawing or cancelling a previous licence issued by that State, the validity of any license that may subsequently be issued to him by another Member State. To accept that a Member State is entitled to rely on its national provisions in order to refuse indefinitely to recognise a license issued by another Member State would be fundamentally incompatible with the principle of mutual recognition of driving licenses which is the linchpin of the system established by Directive (...). it is contrary to those provisions for a Member State, in circumstances such as those of the cases in the main proceedings, to refuse to recognise in its territory the right to drive stemming from a driving license subsequently issued by another Member State following any period in which the person concerned is forbidden to apply for a new license and therefore, the validity of that license, so long as the license-holder has not satisfied the necessary conditions in that first Member State for the issue of a new license following the withdrawal of a previous license, including the examination of fitness to drive certifying that the grounds justifying the withdrawal are no longer in existence. In the same circumstances, it is not contrary to those provisions for a Member State to refuse to recognise in its territory the right to drive stemming from a driving license subsequently issued by another Member State, if it is established, on the basis of entries appearing in the driving license itself or of other incontestable information supplied by the Member State of issue, that when that license was issued its holder, who had been the object, in the territory of the first Member State, of a measure withdrawing an earlier license, was not normally resident in the territory of the Member State of issue." Decision of $26^{\text {th }}$ June 2008, Wiedemann C-329/06 and Funk C-343/06, EU:C:2008:366, sub 60, 63 and 73. 
combat forum shopping, the competence to require for additional verification aims to guarantee a certain degree of security standards. In fact, this competence is provided not only in the sources of EU law, ${ }^{62}$ but also to a certain degree in some international treaties. ${ }^{63}$ Similar to the above-mentioned competence to refuse trans-territorial effects, the competence to require for additional verification is also limited to the territory of the concerned (host) State.

Finally, several applicable sources of EU law provide for "protective" (Schutzklausel) and "emergency" (Notstandmassnahmen) measures. These measures also have their parallels in international law. ${ }^{64}$ These protective and emergency measures must be understood as ultima ratio, as they are per see only temporary ${ }^{65}$ and regularly react on some exceptional risk ${ }^{66}$ or extraordinary situation.

62 E.g. the Directive 2009/100/EC provides (Article 3, Paragraphs 1, 3 and 6) that, subject to paragraphs 3 to 6, each Member State shall recognize for navigation on its national waterways the navigability licenses issued by another Member State in accordance with Article 2 on the same basis as if it had issued those licenses itself. (...) Member States may require that the technical specifications laid down in the Rhine Vessel Inspection Regulation be complied with. They may require the certificate referred to in the second subparagraph of paragraph 2 as evidence of this. (...) Member States may require fulfilment in maritime shipping lanes of additional conditions equivalent to those required for their own vessels. Member States shall inform the Commission of their maritime shipping lanes, the list of which shall be drawn up by the Commission on the basis of the information supplied to it by the Member States.

63 E.g. the Agreement on the Application of Sanitary and Phytosanitary Measures (SPS Agreement) of 1994 provides (Art. 4) that Members shall accept the sanitary or phytosanitary measures of other Members as equivalent, even if these measures differ from their own or from those used by other Members trading in the same product, if the exporting Member objectively demonstrates to the importing Member that its measures achieve the importing Member's appropriate level of sanitary or phytosanitary protection. For this purpose, reasonable access shall be given, upon request, to the importing Member for inspection, testing and other relevant procedures.

64 E.g. the Vienna Convention on Road Traffic of 1968 provides (Art. 42), that Contracting Parties or subdivisions thereof may withdraw from a driver the right to use his domestic or international driving permit in their territories if he commits in their territories a breach of their regulations rendering him liable under their legislations to the forfeiture of his permit. Further, the Convention provides that nothing in it shall be construed as prohibiting Contracting Parties or subdivisions thereof from preventing a driver holding a domestic or international driving permit from driving if it is evident or proved that his condition is such that he is unable to drive safely or if the right to drive has been withdrawn from him in the State in which he has his normal residence.

65 In this respect, the Directive 2009/54/ES provides (Article 11, Paragraph 1), that where a Member State has detailed grounds for considering that a natural mineral water does not comply with the provisions laid down in this Directive, or endangers public health, albeit freely circulating in one or more Member States, that Member State may temporarily restrict or suspend (highlighted by the author) trade in that product within its territory. It shall immediately inform the Commission and the other Member States thereof and give reasons for its decision.

66 E.g. the Directive 2009/100/ES provides (Article 4, Paragraph 2), that any Member State may interrupt the passage of a vessel, where the vessel is found on inspection to be in a condition which constitutes a danger to the surroundings, until the defects have been corrected. That Member State may also do so where the vessel or its equipment is found on inspection not to satisfy the requirements set out in the navigability license or in the other documents referred to in Article 3 as the case may be. 
Consequently, one may argue that the EU law reflects to a certain extent both the above-mentioned doctrines. On one hand, the competence to review legality of the issued act is, in principle, conferred to the administrative authorities of the home State. At the same time, the administrative authorities of the host States posess several competencies to restrict the effects of a foreign administrative act in their territory if they consider such steps necessary to protect the public interests. Consequently, in both cases, the foreign administrative act must be addressed by the administrative authority of the host State.

\subsection{Qualification problems in international administrative law}

Having discussed the problems of nullity and legality of foreign administrative acts, we can now approach the issue of the qualification problem. We have seen several cases of interaction between the administrative authorities of the host State and the foreign administrative acts. Consequently, the question arises ${ }^{67}$ as to which legal framework must be used when dealing with a foreign administrative act.

The qualification problem in international administrative law represents both a complex and demanding exercise. ${ }^{68}$ Foreign administrative acts, which establish legal effects in the model of passive mutual recognition, can be qualified quite differently under the legal framework of the home and the host State. ${ }^{69}$ In this respect, Angelos Gerontas provided ${ }^{70}$ a detailed overview of the mutual incompatibility of the term Verwaltungsakt in the German Verwaltungsrecht with the term acte administratif in the French droit administratif.

Further, Kerstin Reinacher argues, ${ }^{71}$ that there are other administrative measures that are potentially able to establish trans-territorial legal effects in the model of passive mutual recognition. This is, in particular, the case of mutual contracts that replace issuance of an administrative act (öffentlich-rechtliche Verträge) and individualabstract acts (Allgemeinverfügungen).

The qualification problem was already addressed by scholars of international administrative law when dealing with the model of active mutual recognition. In this

67 To a certain extent, the issue was addressed by the session on administrative law at the $19^{\text {th }}$ Congress of the International Academy of Comparative Law. With respect to the qualification problem, it was argued that only the Hungarian legal framework contains explicit provisions on how to deal with foreign administrative acts if they are to be addressed by Hungarian administrative authorities. For details, see AA.VV., General Report related to the "Recognition of foreign administrative acts", In: XIX. Congress of the International Academy of Comparative Law, Vienna, 2014, sub 4.1.

68 Pamboukis, C., Les actes publics et la méthode de réconnaissance, In: Lagarde, P. (ed.) La reconnaissance des situations en droit international privé, Paris, Éd. A. Pedone, 2013, pp. 125145.

69 Bassi, N., Il mutuo riconoscimento in transformazione, Riv.it.dir.pubbl.com., vol. 17, 5/2008, pp. 1520-1521.

70 Gerontas, A., op. cit., pp. 426-428.

71 Reinacher, K., Die Vergemeinschaftung von Verwaltungsverfahren am Beispiel der Freisetzungsrichtlinie, Berlin, Juristische Reihe Tenea, 2005, pp. 61-62. 
respect, Klaus König argued ${ }^{72}$ that there are three possible solutions for this problem: a) the use of the lex causae, i.e. of the legal framework of the home State, b) the use of the lex fori, i.e. of the legal framework of the host State and finally c) an autonomous qualification of foreign administrative act as being an administrative measure sui generis.

\subsubsection{Lex causae}

Taking the principle of the jurisdictional immunity of the State into regard, a foreign administrative act will remain - even after establishing legal effects in the territory of other States - to represent an act issued under the legal framework of the home State. Consequently, the legality (and also potential nullity) of such an act can be, in principle, reviewed only pursuant to this legal framework. ${ }^{73}$ Having said this, one may argue for the use of the lex causae in any cases in which the administrative authorities of the host State will address a foreign act.

However, this approach would, in principle, be in strict contrast with the principle of legality. The administrative authority of the host State cannot - without being required to do so by an explicit provision of the applicable law - apply foreign public law. In fact, such provisions are absent in the existing sources of EU law. ${ }^{74}$ Consequently, the lex causae is not a viable solution to the qualification problem.

\subsubsection{Lex fori}

Taking the principle of legality of the public administration into regard, one may argue that, when addressing a foreign administrative act, the competent administrative authority of the host State must always use their own law (i.e. lex fori). The scholarship of international administrative law had, in fact, $\operatorname{argued}^{75}$ for this approach, when addressing the qualification problem regarding the model of active mutual recognition.

However, this approach also has several disadvantages. In particular, due to absence of any harmonization of the forms of administrative measures within the EU, the use of lex fori can lead to a curious situation, when an act will be simultaneously qualified differently in various host States. ${ }^{76}$ Also, in a hypothetical situation, ${ }^{77}$ the legal framework of the host State will be unable to qualify the nature of the foreign administrative act, due to the absence of a corresponding institute.

72 König, K., op. cit., pp. 32-34.

73 Ohler, C., Die Kollisionsordnung des allgemeinen Verwaltungsrechts: Strukturen des deutschen internationalen Verwaltungsrechts, Tübingen, Mohr Siebeck, 2005, pp. 20-22.

74 Bariatti, S., Reconnaissance et droit de l'Union Européenne, In: Lagarde, P. (ed.) La reconnaissance des situations en droit international privé, Paris, Éd. A. Pedone, 2013, pp. 8698.

75 Biscottini, G., L’efficacité..., pp. 639-640, Issay, E., op. cit., pp. 344-354, Hoffmann, G., op. cit., pp. 851-862, König, K., op. cit., p. 20, Vogel, K., Der räumliche Anwenndungsbereich..., p. 310.

76 De Lucia, L., Amministrazione transnazionale e ordinamento europeo, Torino, G. Giapichelli, 2009, pp. 25-26.

77 Bassi, N., Il mutuo riconoscimento..., p. 1520. 


\subsubsection{Autonomous qualification}

Taking the problems arising by the application of both lex causae and lex fori to the model of passive mutual recognition, it can be also argued that the "trans-territorial administrative acts" actually represent a measure sui generis. This will be in line with the positions of several academicians who described these acts as "a supranational institute" 78 and "measures to enhance a mutual administrative co-operation". 79

However, this approach also implies serious inconsistencies. The applicable directives merely provide for enlarging ${ }^{80}$ of the legal effects of concerned administrative acts and for a corresponding notification procedure, rather than an autonomous framework governing legal nature of such acts. Consequently, very similar to the above-mentioned international treaties, the applicable directives merely rely on the procedural autonomy of the concerned States. Thus, "trans-territorial administrative acts" always represent a measure issued pursuant to the applicable procedural rules of the concerned State. ${ }^{81}$ A myriad of these measures fail to allow an argument for any uniform, autonomous qualification of "trans-territorial administrative acts". The issued act continues ${ }^{82}$ to represent an administrative act of the concerned home State, irrespective of what kind of trans-territorial effects it may provide.

Having presented three different options on solutions to the qualification problem, we conclude that the only viable solution is using the lex fori. Such a result is in line with the doctrine established ${ }^{83}$ by the scholars of international administrative law in the past. Further, only this solution is in line with the principles of legality and procedural autonomy among the concerned States.

\section{FINAL REMARKS}

The provisions of the applicable EU directives on "trans-territorial" effects of administrative acts imply various cases of administrative relations with a foreign element. Such cases were rare in the past, as the sources of international law did

78 Ruffert, M., Der Transnationale Verwatlungsakt..., p. 453-454.

79 Erichsen, H., Ehlers, D., op. cit., 629-630.

80 E.g. the Directive 2009/65/ES provides (Article 5, Paragraph 1), that no undertakings for collective investment in transferable securities shall pursue activities as such unless it has been authorized in accordance with this Directive. Such authorisation shall be valid for all Member States (highlighted by the author). The Directive 2009/138/EC provides (Article 15), that an authorisation for the taking-up of the business of direct insurance or reinsurance covered by this Directive shall be valid for the entire Community (highlighted by the author). It shall permit insurance and reinsurance undertakings to pursue business there, that authorization also covering the right of establishment and the freedom to provide services. The Directive 2011/61/ EC provides (Article 8), that the authorization of the managers of alternative investment funds shall be valid for all Member States (highlighted by the author). The Directive 2013/36/ EC provides (Article 17) the same in a negative way (host Member States shall not require authorization or endowment capital for branches of credit institutions authorized in other Member States) etc.

81 Ruffert, M., Der Transnationale Verwatlungsakt..., p. 453-454.

82 Bassi, N., Il mutuo riconoscimento..., p. 1520.

83 See note 77. Recently, the issue was addressed by Menzel, J., op. cit., pp. 823-824. 
not very frequently apply the model of "trans-territorial" effects. Therefore, it was acceptable for the science of administrative law to deal only with issues concerning the territory of the State and to leave all issues involving a foreign element to international law. However, the increasing number of these provisions in EU law implies various legal questions that are addressed by administrative law, rather than by the scholars of either international or EU law. ${ }^{84}$

Consequently, these developments in EU law trigger ${ }^{85}$ a renaissance of the half-forgotten branch of the administrative; international administrative law (diritto amministrativo internazionale, droit administratif international, internationales Verwaltungsrecht), which represents a kind of parallel to international private law. ${ }^{86}$ The fact is that the doctrine of international administrative law offers solutions in a number of situations in which administrative authorities face circumstances that involve a foreign element.

However, one must take into regard that most of the great scholars of international administrative law (Karl Neumeyer, Paul Négulescu, Giuseppe Biscottini) were active from the 1930s to the 1960s. Thus, there is a gap in academic scholarship, which implies that not all problems can be resolved by the existing doctrine.

This circumstance implies a need for further development of this academic discipline and its gradual inclusion into the mainstream scholarship of administrative law.

Books:

\section{LITERATURE}

1. Bassi, Nicola, Mutuo riconoscimento e tutela giurisdizionale; La circolazione degli effete del provvedimento amministrativo straniero fra diritto europeo e protezione degli interessi del terzo, Milano, Giuffré Editore, 2008

2. Biscottini, Giuseppe, Diritto amministrativo internazionale, vol. II, Padova, Antonio Milani, 1966.

3. Burbaum, Stephan, Rechtsschutz gegen transnationales Verwaltungshandeln, Baden Baden, Nomos Verlag, 2003.

4. Carlston, Kenneth, International Administrative Law: A Venture in Legal Theory, Emory University Law School, 1959.

5. Danwitz, Thomas, Europäisches Verwaltungsrecht, Heidelberg, Springer Verlag, 2008.

6. De Lucia, Luca, Amministrazione transnazionale e ordinamento europeo, Torino, G. Giapichelli, 2009.

7. Erichsen, H., Ehlers, D. (eds.), Allgemeines Verwaltungsrech, Berlin, De Gruyter, 2010.

8. Fedozzi, Prospero, Il Diritto Amministrativo Internazionale (Nozioni Sistematiche), Perugia, Unione Tipografica Cooperativa, 1901.

84 Handrlica, J., Coordinated Administrative Decisions in the EU Law: Some Thorny Issues Arising from the Application of this New Model, The Lawyer Quarterly, vol. 6, 2/2016, pp. 115-116.

85 Biaggini, G., Die Entwicklung eines Internationalen Verwaltungsrechts..., pp. 414-415, Ohler, C., Die Kollisionsordnung..., pp. 20-27.

86 In this regard, it is interesting to note, that a distinction between ,material“ and ,procedural“ international administrative law was proposed in legal scholarship. See Menzel, J., op. cit., pp. 670-672 and 691-692. 
9. Happe, Christian, Die grenzüberschreitende Wirkung von nationalen Verwaltungsakten, Frankfurt am Main, Peter Lang, 1987.

10. Hofmann, Hertwig, Rowe, Gerard, Türk, Alexander, Administrative Law and Policy in the European Union, Oxford, OUP, 2011.

11. Janssens, Christine, The Principle of Mutual Recognition in EU Law, Oxford, OUP, 2013.

12. Jarck, Christian, Abänderung und Aufhebung ausländischer Staatshoheitsakte im internationalen Rechtsverkehr, Göttingen, 1954.

13. Kment, Martin, Grenzüberschreitendes Verwaltungshandeln; Transnationale Elemente deutschen Verwaltungsrechts, Tübingen, Mohr Siebeck, 2010

14. König, Karl, Die Anerkennung der ausländischen Verwaltungsakten, Köln, C. Heymann, 1965.

15. Menzel, Jörg, Internationales Öffentliches Recht, Verfassungs- und Verwaltungsgrenzrecht in Teiten der offenen Staatlichkeit, Tübingen, Mohr Siebeck, 2011.

16. Neumeyer, Karl, Internationales Verwaltungsrecht, Allgemeiner Teil, Zürich, Verlag für Recht und Gesellschaft, 1936.

17. Ohler, Christoph, Die Kollisionsordnung des allgemeinen Verwaltungsrechts: Strukturen des deutschen internationalen Verwaltungsrechts, Tübingen, Mohr Siebeck, 2005.

18. Pamboukis, Charalambos, L'acte public étranger en droit international privé, Paris, L.G.D.J., 1993.

19. Reinacher, Kerstin, Die Vergemeinschaftung von Verwaltungsverfahren am Beispiel der Freisetzungsrichtlinie, Berlin, Juristische Reihe Tenea, 2005.

20. Schlochauer, Hans-Jörgen, Die extraterritoriale Wirkung von Hoheitsakten nach dem öffentlichen Recht der Bundesrepublik Deutschland und nach internationalem Recht, Frankfurt am Main, Vittorio Klosterman, 1962.

21. Siegrist, Dave, Hoheitsakte auf fremdem Staatsgebiet, Zürich, Schulthess Verlag, 1987.

22. Sydow, Gernot, Verwaltungskooperation in der Europäischen Union, Tübingen, Mohr Siebeck, 2004.

23. Vogel, Klaus, Der räumliche Anwenndungsbereich der Verwaltungsnormen, Frankfurt am Main, Alfred Metzner Verlag, 1965.

24. Weil, Prosper, Le droit administratif international: bilan et tendences, Paris, Institut des hautes études internationales, 1962.

25. Weiss, Käte, Die Annerkennung ausländischer Verwaltungsakte, Flentje, Verlag Seesen, 1932.

Contributions in collective works:

1. Bariatti, Stefania, Reconnaissance et droit de l'Union Européenne, In: Lagarde, P. (ed.) La reconnaissance des situations en droit international privé, Paris, Éd. A. Pedone, 2013, pp. 86-98.

2. Battini, Stefano, Il diritto amministrativo internazionale, Riv. it. dir. pubbl. com., 10/2010, pp. 1405-1427.

3. Biaggini, Giovanni, Die Entwicklung eines Internationalen Verwaltungsrechts als Aufgabe der Rechtswissenschaft, In: Nolte, G., Poscher, R., Hillgruber, C. (eds.), Die Leistungsfähigkeit der Wissenschaft des Öffentlichen Rechts, Berlin, De Gruyter, 2008, pp. 413-445.

4. Beitzke, Günther, Extraterritoriale Wirkung von Hoheitsakten, In: Strupp, K., Schlochauer, H. (eds.) Wörterbuch des Völkerrechts, De Gruyter, Berlin, 1960, pp. 505-506.

5. Bollée, Sylvain, Les conditions de la reconnaissance, notamment à la lumière des conventions internationales, In: Lagarde, P. (ed.) La reconnaissance des situations en droit international privé, Paris, Éd. A. Pedone, 2013, pp. 112-122.

6. Breining-Kaufmann, Christine, Internationales Verwaltungsrecht, Zeitschrift für Schweizerisches Recht, vol. 125, 1/2006, pp. 7-46. 
7. Clarizia, Paolo, Il mutuo riconoscimento e la differenziazione dei diritti nell' Unione europea, In : Torchia, L. (ed.), Diritto amministrativo progredito, Bologna, Il Mulino, 2010, pp. 306-324.

8. Dahm, G., Die Achtung fremder Hoheitsakte, In: Dahm, G., Delbrück, J., Wolfrum, R. (eds.), Völkerrecht, Die Grundlagen, Die Völkerrechtssubjekte, Berlin, De Gruyter, 1989, pp. 482-494.

9. Della Cananea, Giacinto, From the Recognition of Foreign Acts to Trans-national Administrative Procedures, In: Rodríguez-Arana Munoz, J. (ed.), Recognition of Foreign Administrative Acts, New York, Springer, 2016, pp. 219-242.

10. Geck, Walter, Anerkennung fremder Hoheitsakte, In: Strupp, K., Schlochauer, H. (eds.) Wörterbuch des Völkerrechts, De Gruyter, Berlin, 1960, s. 55-57.

11. Geck, Walter, Hoheitsakte auf fremden Staatsgebiet, In: Strupp, K., Schlochauer, H. (eds.) Wörterbuch des Völkerrechts, De Gruyter, Berlin, 1960, s. 795-796.

12. Hoffmann, Gerhard, Internationales Verwaltungsrecht, In: Münch, I. (ed.) Besonderes Verwaltungsrecht, Berlin, De Gruyter, 1985, pp. 851-862.

13. Issay, Ernst, Internationales Verwaltungsrecht, In: Stier-Slomo, F., Elster, A. (eds.) Handwörterbuch der Rechtswissenschaft, vol. 3, Berlin, De Gruyter, 1928, pp. 344-354.

14. Matscher, Franz, Gibt es ein internationales Verwaltungsrecht? In: Sandrock, O. (ed.), Festschrift für Günther Beitzke, Berlin, De Gruyter, 1979, pp. 641-649.

15. Mayer, Pierre, Les méthodes de la reconnaissance en droit international privé, In: Mélanges en l'honneur de Paul Lagarde, Le droit international privé : esprit et méthodes, Paris, Ed. Dalloz, 2005, pp. 547-552.

16. Ohler, Christoph, Internationales Verwaltungsrecht - ein Kollisionsrecht eigener Art? In: Leible, S., Ruffert, M. (eds.), Völkerrecht und IPR, Jena, Jaener Wissenschaftlicher Verlag, 2006, pp. 131-148.

17. Pamboukis, Charalambos, Les actes publics et la méthode de réconnaissance, In: Lagarde, P. (ed.) La reconnaissance des situations en droit international privé, Paris, Éd. A. Pedone, 2013, pp. 125-145.

18. Pernas García, Juan José, The EU's Role in the Progress Towards the Recognition and Execution of Foreign Administrative Acts, In: Rodríguez-Arana Munoz, J. (ed.), Recognition of Foreign Administrative Acts, New York, Springer, 2016, pp. 15-33.

19. Raschauer, Bernhard, Transnationale Verwaltungsakten, In: Hammer, S., Stelzer, M., Weichselbaum, B. (eds.), Demokratie und sozialer Rechtsstaat in Europa; Festschrift für Theo Öhlinger, Wien, WUV Universitätsverlag, 2004, pp. 661-686.

20. Ritleng, Dominique, Le retrait des actes administratifs contraires au droit communautiare, In: Schwarze, J. (ed.), L'état actuel et les perspectives du droit administratif européen, Brussels, Bryulant, 2010, pp.. 251-271.

21. Ruffert, Matthias, Perspektiven des Internationalen Verwaltungsrechts, In: Möllers, C., Vosskuhle, A., Walter, C. (eds.), Internationales Verwaltungsrecht, Tübingen, Mohr Siebeck, 2007, pp. 395-420.

22. Ruffert, Matthias, Recognition of Foreign Legislative and Administrative Act, In: Wolfrum, R. (ed.), Max Planck Encyclopedia of Public International Law, Oxford, OUP, 2008, pp. 567-578.

23. Schwarz, Martin, Europa in der Horizontalen: Zur Abgrenzung des Prinzips gegenseitiger Anerkennung von Rechtsinstitut des transnationalen Verwaltungsaktes, In: Debus, A., Kruse, F., Peters, A. (eds), Verwaltungsrechtsraum Europa, Baden Baden, Nomos Verlag, 2011, pp. 53-69.

24. Vogel, Klaus, Administrative Law. International Aspects, In: Encyclopedia of Public International Law, Vol. 9 - International Relations and Legal Co-operation in General, Amsterdam, North Holland, 1986, pp. 4-5. 
Journal articles:

1. Bassi, Nicola, Il mutuo riconoscimento in transformazione, Riv.it.dir.pubbl.com., vol. 17, 5/2008, pp. 1517-1523.

2. Biscottini, Giuseppe., L'efficacité des actes administratifs étrangers, RCADI, vol. 103, 5/1961, 638-696.

3. Bocanegra Sierra, Raúl, Garcia Luengo, Javier, Los actos administrativos transnacionales, Revista de Administración Pública, num. 177, 2008, septiembre/diciembre, pp. 9-29.

4. Borsi, Umberto, Carattere e oggetto del diritto amministrativo internazionale, RDI, vol. 2, 2/1912, pp. 352-378.

5. De Lucia, Luca, Autorizzazioni transnazionali e cooperazione amministrativa nell'ordinamento europeo, Riv.it.dir.pubbl.com., vol. 19, 3/4/ 2010, pp. 759-788.

6. De Lucia, Luca, Administrative Pluralism, Horizontal Cooperation and Transnational Administrative Acts, REALaw, vol. 5, 2/2012, s. 14-45.

7. De Lucia, Luca, From Mutual Recognition to EU Authorization: A Decline of Transnational Administrative Acts? I.J.P.L., vol. 8, 1/2016, pp. 90-118.

8. Fedozzi, Prospero, De l'efficacité extraterritoriale des lois et des actes de droit public, RCADI, vol. 32, 1/1929, pp. 141-242.

9. Gascón y Marín, José, Les transformations du droit administratif international, RCADI, vol. 33, 1/1930, pp. 1-76.

10. Gerontas, Angelos, Deterritorialization in Administrative Law: Exploring Transnational Administrative Decisions, Columbia Journal of European Law, vol. 19, 3/2013, pp. 423468.

11. Handrlica, Jakub, International Administrative Law and Administrative Acts: Transterritorial Decision Making Revisited, Czech Yearbook of Public \& Private International Law, vol. 7, 2016, pp. 86-100.

12. Handrlica, Jakub, Coordinated Administrative Decisions in the EU Law: Some Thorny Issues Arising from the Application of this New Model, The Lawyer Quarterly, vol. 6, 2/2016, pp. 109-116.

13. Handrlica, Jakub, Foreign Law as Applied by Administrative Authorities: Grenznormen Revisited, Collected Papers of Zagreb Law Faculty, vol. 68, 2/2018, pp. 193-215.

14. Hofmann, Hertwig, Dealing with Trans-Territorial Executive Rule Making, Mo.L.Rev., vol. 78, 2/2013, pp. 423-442.

15. Hofmann, Hertwig, Seven Challenges for EU Administrative Law, REALaw, vol. 2, 1/2009, pp. 37-59.

16. Kazansky, Pierre, Les premiers éléments de l'organisation universelle, RDILC, vol. XXIX, 1/1897, pp. 238-247.

17. Kinney, Eleanor, The emerging field of international administrative law: its content and potential, ALR, vol. 54, 1/2002, pp. 415-433.

18. Morgenstern, Felice, Recognition and Enforcement of Foreign Legislative, Administrative and Judicial Acts which are contrary to International Law, ILQ, vol. 4, 3/1951, pp. 326344

19. Négulescu, Paul, Principes du droit international administratif, RCADI, vol. 4, 4/1935, pp. 579-692.

20. Neßler, Volker, Der transnationale Verwaltungsakt: zur Dogmatik eines neuen Rechtsinstituts, NVwZ, vol. 14, 10/1995, pp. 863-873.

21. Pamboukis, Charalambos, L'acte quasi public en droit international privé, Rev.crit. DIP, 1993, pp. 565-585.

22. Pamboukis, Charalambos, La renaissance-métamorphose de la méthode de reconnaissance, Rev.crit. DIP, 2008, pp. 513-528.

23. Ruffert, Matthias, Der Transnationale Verwatlungsakt, Verw, vol. 34, 3/2001, pp. 453-470.

24. Stelkens, Ulrich, Europäische Rechtsakte als „Fundgrube“ für allgemeine Grundsätze des 
deutchen Verwaltungsverfahrensrechts, ZEuS, vol. 1, 1/2004, 129-164.

25. Wenander, Henrik, Recognition of Foreign Administrative Decisions, Balancing International Co-operation, National Self-Determination and Individual Rights, ZaöRV, vol. 71, 1/2011, s. 755-785.

Reports:

1. AA.VV., General Report related to the "Recognition of foreign administrative acts", In: XIX. Congress of the International Academy of Comparative Law, Vienna, 2014.

Working papers:

1. Hofmann, H., Transnational and Trans-Territorial Rule-Making - A Basic Framework, Law Working Papers, University of Luxembourg, 1/2014, pp. 1-40. 


\section{Jakub Handrlica*}

Sažetak

\section{REVIDIRANJE MEĐUNARODNOG UPRAVNOG PRAVA KAO PRAVNE DISCIPLINE}

Značenje naziva „međunarodno upravno pravo“ se do sada interpretiralo na dva načina. S jedne strane su autori koristili taj naziv (diritto internazionale amministrativo) odnoseći se na upravne kompetencije različitih međunarodnih upravnih udruženja, kako je predviđeno mjerodavnim međunarodnim konvencijama. Drugi su autori (npr. Karl Neumeyer, Paul Négulescu, Giuseppe Biscottini) taj naziv koristili isključivo odnoseći se na norme nacionalnog prava (diritto amministrativo internazionale, droit administratif international, internationales Verwaltungsrecht), koje su uključivale neke strane elemente. U ovom se radu naziv „međunarodno upravno pravo" interpretira prema potonjem značenju. Činjenica jest da su te norme bile iznimno rijetke u upravnom pravu, zbog čega pravna znanost nije posvećivala previše pozornosti disciplini međunarodnog upravnog prava. No, u posljednje vrijeme izvori prava Europske unije sve više zahtijevaju razmatranje određenih stranih elemenata u normama upravnog prava. $U$ tom se pogledu u ovom radu zauzima stav da je međunarodno upravno pravo pravna disciplina koja može riješiti probleme nastale primjenom navedenih normi upravnog prava.

Ključne riječi: međunarodno upravno pravo, uzajamno priznavanje stranih upravnih akata, acta iure imperii, problem kvalifikacije, sudski imunitet države.

\section{Zussamenfassung}

\section{INTERNATIONALES VERWALTUNGSRECHT ALS REVIDIERTE RECHTSDISZIPLIN}

Der Begriff "internationales Verwaltungsrecht" kann zweierlei ausgelegt werden. Einerseits wurde der Begriff (diritto internazionale amministrativo) im Kontext von verwaltungsrechtlichen Kompetenzen unterschiedlicher internationaler Verwaltungsorganisationen benutzt, wie das von den einschlägigen internationalen Konventionen vorgesehen wird. Andererseits benutzten manche Autoren (z.B. Karl Neumeyer, Paul Négulescu, Giuseppe Biscottini) diesen Begriff, um ausschließlich

* Doc. JUDr. Jakub Handrlica, Ph.D., Associate Professor, Faculty of Law, Charles University in Prague, Czech Republic; jakub.handrlica@prf.cuni.cz. 
auf die Normen des nationalen Rechts mit internationalem Charakter hinzuweisen (diritto amministrativo internazionale, droit administratif international, internationales Verwaltungsrecht). In diesem Beitrag wird dieser Begriff im Sinne der letztgenannten Auslegung verstanden. Es besteht die Tatsache, dass diese Normen sehr selten im Verwaltungsrecht benutzt wurden, weshalb die Rechtswissenschaft keinen großen Wert auf die Disziplin des internationalen Verwaltungsrechts legte. Erst kürzlich wird in den Quellen der EU die Benutzung mancher internationalen Elemente in den Normen des Verwaltungsrechts sichtbar. Diesbezüglich wird in diesem Beitrag behauptet, dass das internationale Verwaltungsrecht eine Rechtsdisziplin darstellt, welche fähig ist, die aus der Anwendbarkeit dieser Normen des internationalen Verwaltungsrechts hervorgehenden Probleme anzusprechen.

Schlüsselwörter: internationales Verwaltungsrecht, gegenseitige Anerkennung von fremden Verwaltungsakten, acta iure imperii, Qualifizierungsproblem, Immunität des Staates von der Gerichtsbarkeit.

\section{Riassunto}

\section{IL RIPENSAMENTO DEL DIRITTO INTERNAZIONALE AMMINISTRATIVO QUALE DISCIPLINA GIURIDICA}

Il significato del termine „diritto internazionale amministrativo" fino ad ora è stato interpretato in due modi. Da un lato gli autori utilizzavano tale termine (diritto internazionale amministrativo) riferendosi alle competenze amministrative di diversi enti amministrativi internazionali, così come previsto dalle convenzioni internazionali applicabili. Altri autori (ad es. Karl Neumeyer, Paul Négulescu, Giuseppe Biscottini) usavano tale termine esclusivamente riferendosi alle norme del diritto nazionale (diritto amministrativo internazionale, droit administratif international, internationales Verwaltungsrecht), le quali includevano alcuni elementi stranieri. Nel presente lavoro il termine,, diritto internazionale amministrativo" viene interpretato in tale ultima maniera. Il fatto è che tali norme erano estremamente rare nel diritto amministrativo, per la quale ragione la scienza giuridica non prestava particolare attenzione alla disciplina del diritto internazionale amministrativo. Invece, in tempi recenti, le fonti giuridiche dell'Unione europea sempre di più pretendono l'analisi di determinati elementi stranieri all'interno della disciplina del diritto amministrativo. In tale senso, nel presente lavoro si prende posizione a favore dell'orientamento che reputa il diritto internazionale amministrativo capace di risolvere le questioni sorte in seguito all'applicazione delle menzionate norme del diritto amministrativo.

Parole chiave: diritto internazionale amministrativo, mutuo riconoscimento degli atti amministrativi stranieri, acta iure imperii, problema di qualificazione, immunità giudiziale dello stato. 